First publ. in: Archives of Microbiology 162 (1994), 3, pp.199-204

Joachim Frings · Bernhard Schink

\title{
Fermentation of phenoxyethanol to phenol and acetate by a homoacetogenic bacterium
}

Received: 2 March 1994 / Accepted: 2 May 1994

\begin{abstract}
A strictly anaerobic gram-positive, rod-shaped bacterium, strain LuPhet1, was isolated from sewage sludge with phenoxyethanol as sole carbon and energy source, and was assigned to the genus Acetobacterium. The new isolate fermented the alkylaryl ether compound phenoxyethanol stoichiometrically to phenol and acetate, whereas phenoxyacetic acid was not degraded. In cell-free extracts of strain LuPhet1, cleavage of the ether linkage was shown, and acetaldehyde was detected as reaction product. Coenzyme A-dependent acetaldehyde:acceptor oxidoreductase, phosphate acetyltransferase, acetate kinase, and carbon monoxide dehydrogenase were measured in cell-free extracts of this strain. Our results indicate that the ether linkage of phenoxyethanol is cleaved by a shift of the hydroxyl group to the subterminal carbon atom, analogous to a corrinoid-dependent diol dehydratase reaction, to form an unstable hemiacetal that releases phenol and acetaldehyde. Obviously, phenoxyethanol is degraded by the same strategy as in anaerobic degradation of the alkyl ether polyethylene glycol.
\end{abstract}

Key words Anaerobic degradation - Phenoxyethanol Ether cleavage - Homoacetogenic fermentation Corrinoids

\section{Introduction}

Ether linkages occur in many natural or synthetic compounds. For example, the aryl-glycerol- $\beta$-aryl-ether linkage is the most important linkage type of lignin (Adler 1977). Ether linkages are also major structural linkages of coal (Heredy and Wender 1980). Many synthetic ether compounds are released into the environment at high rates. For instance, chlorinated phenoxyalkanoic acids (2,4-dichlorophenoxyacetic acid or 2,4,5-trichlorophen-

J. Frings $\cdot$ B. Schink $(\varangle)$

Fakultät für Biologie, Universität Konstanz, Postfach 5560,

D-78434 Konstanz, Germany oxyacetic acid) are among the most abundant herbicides produced globally (Ghosal et al. 1985).

Ether linkages are comparably stable and are a considerable problem for microbial degradation. In the presence of molecular oxygen, ether linkages are usually cleaved by monooxygenase reactions that transform the ether linkage through hydroxylation to a hemiacetal structure of low stability (Bernhardt et al. 1970; Stirling and Dalton 1980). Under anoxic conditions, alternative ether cleavage reactions must be involved. In anaerobic degradation of the alkyl ether polyethylene glycol (PEG), the ether linkage is converted through a corrinoid-dependent hydroxyl shift reaction into an unstable hemiacetal structure that releases acetaldehyde as the first reaction product (Schramm and Schink 1991; Frings et al. 1992).

Little is known about cleavage of alkylaryl or biaryl ether linkages under anoxic conditions. In the present study, we chose phenoxyethanol as a model substrate of an alkylaryl ether to investigate the ether cleavage reaction.

\section{Material and methods}

Source of organisms

Strain LuPhet1 was isolated from anoxic digested sludge of the municipal sewage plant in Tübingen-Lustnau, Germany.

Media and growth conditions

Carbonate-buffered, sulfide-reduced mineral medium was prepared as previously described (Widdel and Pfennig 1981), containing 7-vitamin solution (Widdel and Pfennig 1981), selenitetungstate solution (Tschech and Pfennig 1984) and the trace element solution SL 10 (Widdel et al. 1983). The final $\mathrm{pH}$ of the medium was adjusted to $7.2-7.4$. The growth temperature was $28-30^{\circ} \mathrm{C}$.

\section{Isolation and characterization}

Pure cultures were obtained by using the agar shake culture method (Pfennig 1978). Purity was checked microscopically and 
by growth tests in medium containing $5 \mathrm{~m} M$ fumarate, $5 \mathrm{~m} M$ pyruvate, $0.05 \%$ yeast extract, and $5 \mathrm{~m} M$ phenoxyethanol. Gram staining was carried out according to Bartholomew (1962). The DNA base composition was determined by HPLC (Tamaoka and Komagata 1984; Mesbah et al. 1989) after extraction of DNA according to Marmur (1961). The DNA of bacteriophage $\lambda$ was used as a reference. Substrate utilization was tested in $22-\mathrm{ml}$ screw-cap tubes. Substrates were added from neutralized and filter-sterilized stock solutions. Utilization of $\mathrm{H}_{2}$ was tested in $15-\mathrm{ml}$ Hungate tubes sealed with butyl rubber septa with $10 \mathrm{ml}$ basal medium under an atmosphere of $\mathrm{H}_{2} / \mathrm{CO}_{2}(80: 20)$. Optical densities were measured directly in a Bausch and Lomb Spectronic 20 spectrophotometer (Milton Roy, Rochester, N.Y., USA) in 22-ml screw-cap tubes. Cell dry mass was calculated from turbidity at $578 \mathrm{~nm}$ using the conversion factor $0.1 \mathrm{OD}_{578}=24.7 \mathrm{mg}$ dry mass per liter, which was obtained by direct gravimetric determinations in 1-1 cultures grown with phenoxyethanol.

\section{Preparation of cell-free extracts}

Cells were harvested in the late exponential phase $\left(\mathrm{OD}_{578}=0.1\right)$ by centrifugation under anoxic conditions for $30 \mathrm{~min}$ at $4^{\circ} \mathrm{C}$ and 3000 $\times g$ in 125-ml infusions bottles (Müller \& Krempel, Bülach, Switzerland). The pellet was washed once with $50 \mathrm{~m} M$ potassium phosphate buffer ( $\mathrm{pH} 7.0$ ), prereduced with $2.5 \mathrm{~m} M$ titanium(III) citrate, and resuspended in the same buffer. Cell-free extracts were prepared by five passes through a $\mathrm{N}_{2}$-flushed French pressure cell at $138 \mathrm{MPa}$, and centrifuged at $3000 \times g$ to remove cell debris, Cells were enzymatically broken using lysozyme $(1 \mathrm{mg}$ per $20 \mathrm{mg}$ cell dry mass) in $10 \mathrm{mM}$ Tris/HCl buffer (pH 8.0) containing 10 $\mathrm{m} M$ EDTA, or using mutanolysine (100 $\mathrm{U}$ per mg cell protein) in $50 \mathrm{mM}$ potassium phosphate buffer ( $\mathrm{pH} 7.0$ ), prereduced with 2.5 $\mathrm{m} M$ titanium(III) citrate. Cells were incubated at $37^{\circ} \mathrm{C}$ for $60 \mathrm{~min}$ in both cases.

For light-treatment of cell-free extracts, a cold-light halogen lamp ( $150 \mathrm{~W})$ was used. The vial was exposed for $10 \mathrm{~min}$ to a light intensity of $1400 \mu \mathrm{mol} \mathrm{s}-1 \mathrm{~m}^{-2}$, measured with a Li-189 (LI-COR, Lincoln, Neb., USA) quantum meter with a quantum sensor.

\section{Enzyme assays}

All enzyme assays were carried out under strictly anoxic conditions in $\mathrm{N}_{2}$-gassed and rubber-sealed cuvettes. Activities were measured photometrically in a Hitachi 100-40 spectrophotometer (Hitachi, Tokyo, Japan). The phenoxyethanol-degrading enzyme activity was determined as the NADH-dependent reduction of acetaldehyde formed detected at $340 \mathrm{~nm}$ (modified after Toraya and Fukui 1982). The reaction mixture contained $500 \mathrm{mM}$ potassium phosphate buffer ( $\mathrm{pH} 8.0$ ), prereduced with $2.5 \mathrm{~m} M$ titanium(II) citrate, $0.2 \mathrm{~m} M \mathrm{NADH}, 10 \mathrm{U}$ alcohol dehydrogenase, and $100 \mathrm{~m} M$ phenoxyethanol. Diol dehydratase was assayed in the same manner with $100 \mathrm{mM}$ ethylene glycol. Phosphate acetyltransferase and acetate kinase were measured by standard methods (Bergmeyer 1983). Acetaldehyde: acceptor oxidoreductase and pyruvate:acceptor oxidoreductase were determined with benzyl viologen as electron acceptor (modified after Odom and Peck 1981). Carbon monoxide dehydrogenase was assayed with benzyl viologen as electron acceptor (Diekert and Thauer 1978).

\section{Chemical analyses}

Acetate was determined by gas chromatography as previously described (Platen and Schink 1987). Phenoxyethanol and phenol were analyzed by HPLC with a mixture of $70 \% 100 \mathrm{~m} M$ ammonium phosphate buffer ( $\mathrm{pH} 2.6$ ) and $30 \%$ methanol as mobile phase (Brune and Schink 1990). Protein was determined as described by Bradford (1976) using bovine serum albumin as the reference.

\section{Chemicals}

Chemicals were obtained from Boehringer (Mannheim, Germany), Fluka (Neu-Ulm, Germany), Merck (Darmstadt, Germany), and Sigma (Deisenhofen, Germany). All chemicals were of analytical quality. Gases were obtained from Messer Griesheim (Darmstadt, Germany) and from Sauerstoffwerk (Friedrichshafen, Germany).

\section{Results}

\section{Enrichment and isolation}

Phenoxyethanol-degrading bacteria were enriched in serum bottles containing $50 \mathrm{ml}$ of freshwater or saltwater medium with $5 \mathrm{~m} M$ phenoxyethanol and about $5 \mathrm{ml}$ of anoxic mud from various freshwater and marine habitats. After five transfers, strain LuPhet1 was isolated by two subsequent agar shake dilutions with the same substrate.

\section{Morphology and cytology}

Cells of strain LuPhet1 were straight rods with rounded to slightly pointed ends, $1.0 \times 1.5-3.5 \mu \mathrm{m}$ in size (Fig. 1). They occurred singly, in pairs, or in short chains. Cells

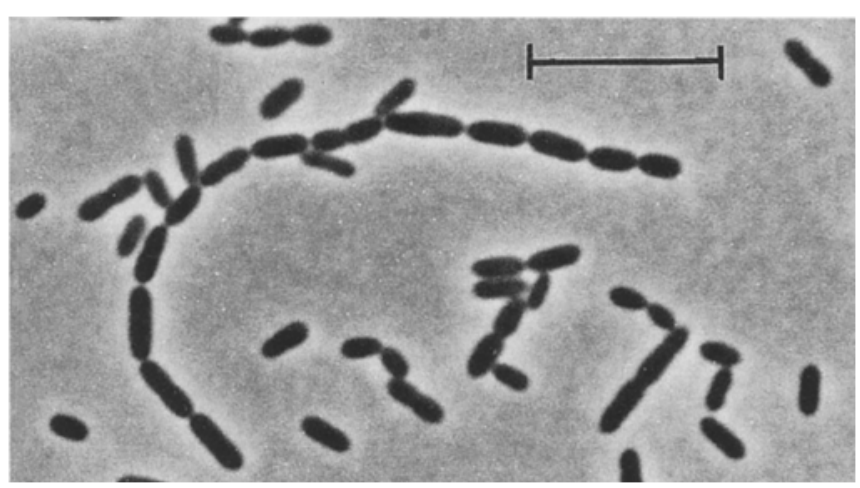

Fig. 1 Phase contrast photomicrograph of strain LuPhet1. Bar 10 $\mu \mathrm{m}$

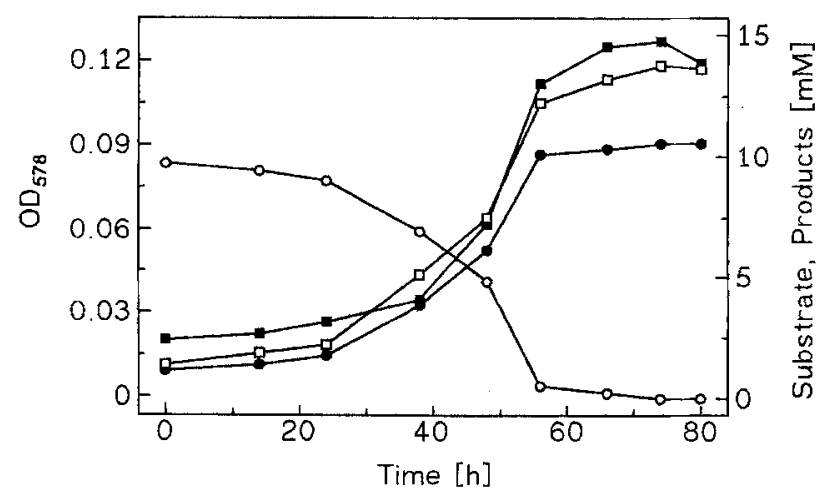

Fig. 2 Fermentation time course of strain LuPhet1 growing with $10 \mathrm{~m} M$ phenoxyethanol as substrate. $O D_{578}$ Optical density at 578 $\mathrm{nm}$. Cell density; $O$ phenoxyethanol; 0 phenol; $\square$ acetate 
Table 1 Substrates tested for growth with strain LuPhet1. Concentration of substrates added was $10 \mathrm{~m} M$ unless indicated otherwise in parentheses

\section{Substrates utilized:}

$\mathrm{H}_{2} / \mathrm{CO}_{2}(80 \% / 20 \%), 3,4,5$-trimethoxybenzoate (2), 3,4,5-trimethoxycinnamate (2), ethylene glycol, 1,2-propanediol, 2,3-butanediol, acetoin, glycerol, lactate, pyruvate, fructose (5), betaine, phenoxyethanol, diethylene glycol, triethylene glycol, PEG 200, methoxyethanol, ethoxyethanol

\section{Substrates not utilized:}

Formate, methanol, ethanol, propanol, butanol, pentanol, fumarate, malate, glucose (5), choline (5), ethanolamine, methoxyacetate, phenoxyacetic acid (1), PEG $400(0.1 \%)$, PEG $1000(0.1 \%)$, PEG 10,000 (0.1\%), PEG 20,000 (0.1\%), tetraethylene glycoldimethylether

were motile in the early exponential growth phase, but lost motility in aging cultures. Spores were never detected, and the cells were gram-positive. The $\mathrm{G}+\mathrm{C}$ content of the DNA was $44.3 \pm 0.6 \mathrm{~mol} \%$.

\section{Physiology}

The new isolate grew only in freshwater medium reduced with sodium sulfide. $\mathrm{NaCl}$ was tolerated up to a concentration of $10 \mathrm{~g} / \mathrm{l}$. Growth was not inhibited by up to 50 $\mathrm{m} M$ phosphate. The $\mathrm{pH}$ range was $6.0-8.0$ with an optimum at $\mathrm{pH} 7.0-7.5$. The optimal growth temperature was 25 to $30^{\circ} \mathrm{C}$ with a doubling time of $8.5 \mathrm{~h}$ (Fig. 2); below $12^{\circ} \mathrm{C}$ and above $37^{\circ} \mathrm{C}$, no growth occurred. Phenoxy- ethanol was fermented to phenol and acetate, approximately according to the following equation:

$$
\begin{aligned}
& 4 \mathrm{C}_{6} \mathrm{H}_{5} \mathrm{OCH}_{2} \mathrm{CH}_{2} \mathrm{OH}+2 \mathrm{CO}_{2}+2 \mathrm{H}_{2} \mathrm{O} \\
& \rightarrow 4 \mathrm{C}_{6} \mathrm{H}_{5} \mathrm{OH}+5 \mathrm{CH}_{3} \mathrm{COO}^{-}+5 \mathrm{H}^{+}
\end{aligned}
$$

$\mathrm{H}_{2} / \mathrm{CO}_{2}$, ethylene glycol, 1,2-propanediol, 2,3-butanediol, acetoin, glycerol, lactate, pyruvate, fructose, betaine, methoxyethanol, ethoxyethanol, and PEG up to a molecular mass of $200 \mathrm{D}$ were utilized as growth substrates (Table 1). Trimethoxybenzoate and trimethoxycinnamate were demethylated to the respective hydroxy derivatives plus acetate. Acetate was determined quantitatively; the degradation products of the aromatic compounds were determined semi-quantitatively by UV-spectroscopy. Fermentation stoichiometries and growth yields are presented in Table 2. Neither inorganic electron acceptors such as sulfate, thiosulfate, sulfur or nitrate, nor fumarate was reduced.

\section{Enzyme activities}

All enzyme activities were assayed in cell-free extracts of strain LuPhetl obtained by disruption with a French pressure cell because neither lysozyme nor mutanolysine lysed the cells. A phenoxyethanol-degrading enzyme activity forming acetaldehyde as reaction product was measured at low activity (Table 3 ). This enzyme activity was stable only for a few hours and accounted for $4 \%$ of the physiological activity of cells growing exponentially with phenoxyethanol $\left[1.04 \mu \mathrm{mol} \mathrm{min}^{-1}\right.$ (mg protein) $\left.{ }^{-1}\right]$. In the enzyme assay, phenoxyethanol cleavage was not influ-

Table 2 Fermentation stoichiometries and growth yields of strain LuPhet1

\begin{tabular}{llllllrr}
\hline Substrate & $\begin{array}{l}\text { Substrate } \\
\text { added } \\
(\mu \mathrm{mol})\end{array}$ & $\begin{array}{l}\text { Cell dry } \\
\text { mass formed } \\
(\mathrm{mg})\end{array}$ & $\begin{array}{l}\text { Acetate } \\
\text { assimilated } \\
(\mu \mathrm{mol})\end{array}$ & $\begin{array}{l}\text { Acetate } \\
\text { formed } \\
(\mu \mathrm{mol})\end{array}$ & $\begin{array}{l}\text { Phenol } \\
\text { formed } \\
(\mu \mathrm{mol})\end{array}$ & $\begin{array}{l}\text { Electron } \\
\text { recovery } \\
(\%)\end{array}$ & $\begin{array}{l}\text { Molar } \\
\text { growth yield } \\
(\mathrm{g} / \mathrm{mol})\end{array}$ \\
\hline Phenoxyethanol & 1000 & 2.70 & 55.5 & 1255 & 965 & 99 & 2.6 \\
Diethylene glycol & 220 & 1.22 & 25.2 & 544 & - & 104 & 5.5 \\
L-Lactate & 220 & 0.95 & 19.6 & 315 & - & 102 & 4.3 \\
3,4,5-Trimethoxybenzoate & 110 & 1.43 & 29.5 & 213 & - & $99^{c}$ & 13.0 \\
3,4,5-Trimethoxycinnamate & 110 & 1.20 & 25.0 & 180 & - & $98^{c}$ & $11.0^{c}$ \\
\hline
\end{tabular}

${ }^{\text {a }}$ Cell dry mass was calculated from cell density using an experimentally determined conversion factor $(0.1$ OD $578=24.7 \mathrm{mg}$ dry cell mass $1^{-1}$ )

$b$ Acetate assimilated was calculated according to the formula: $17 \mathrm{CH}_{3} \mathrm{COOH} \rightarrow\left(\mathrm{C}_{4} \mathrm{H}_{7} \mathrm{O}_{3}\right)+\mathrm{CO}_{2}+\mathrm{H}_{2} \mathrm{O}$

c Values refer only to utilization of methyl groups

Table 3 Enzymes measured in cell-free extracts of strain LuPhet1 grown with phenoxyethanol

\footnotetext{
a Coenzyme $\mathrm{B}_{12}$-dependent

b Benzyl viologen and coenzyme A-dependent

c With benzyl viologen as

\begin{tabular}{|c|c|c|}
\hline Enzyme & EC number & $\begin{array}{l}\text { Specific activity } \\
{\left[\mu \mathrm{mol} \mathrm{min}^{-1}(\mathrm{mg} \text { protein })^{-1}\right]}\end{array}$ \\
\hline Phenoxyethanol-degrading enzyme & $?$ & 0.045 \\
\hline Diol dehydratase $\mathrm{a}^{\mathrm{a}}$ & 4.2 .1 .28 & 0.94 \\
\hline Acetaldehyde: acceptor oxidoreductase ${ }^{b}$ & 1.2.1.10 & 2.82 \\
\hline Phosphate acetyltransferase & 2.3 .1 .8 & 28.05 \\
\hline Acetate kinase & 2.7 .2 .1 & 1.22 \\
\hline CO dehydrogenase ${ }^{c}$ & 1.2 .99 .2 & 3.65 \\
\hline Pyruvate: acceptor oxidoreductase ${ }^{b}$ & 1.2 .7 .1 & 0.15 \\
\hline
\end{tabular}
electron acceptor
} 
enced by various corrinoids (adenosylcobalamin, cyanocobalamin, and hydroxocobalamin). In cell-free extracts of strain LuPhet1, a diol dehydratase activity was also detected. The reaction was stimulated 3.5 -fold by added adenosylcobalamin (coenzyme $\mathrm{B}_{12}, 20 \mu M$ ) and inhibited completely by cyanocobalamin (vitamin $\mathrm{B}_{12}, 20 \mu M$ ) or hydroxocobalamin $(20 \mu M)$. The diol dehydratase activity was reduced to $10 \%$ of the original activity by treatment of cell-free extracts with light, and this effect was alleviated by addition of adenosylcobalamin $(20 \mu M)$. Light had no effect on the phenoxyethanol-degrading enzyme activity. Coenzyme A-dependent acetaldehyde:acceptor oxidoreductase, phosphate acetyltransferase, acetate kinase, and carbon monoxide dehydrogenase were all found at sufficient activities (Table 3 ).

\section{Discussion}

\section{Physiology and biochemistry}

In the present study, cleavage of the aryl ether compound phenoxyethanol in the absence of molecular oxygen is documented for the first time. Phenoxyethanol is degraded by the new isolate, strain LuPhet1, to phenol and acetate. The central problem in anaerobic degradation of phenoxyethanol is the cleavage of the comparably stable alkylaryl ether linkage. In cell-free extracts of strain LuPhet1, a phenoxyethanol-degrading enzyme activity was detected that formed acetaldehyde as product. This result indicates that in the first step the terminal hydroxyl group of phenoxyethanol is shifted to the subterminal carbon atom, analogous to a coenzyme $B_{12}$-dependent diol dehydratase reaction (Toraya and Fukui 1982). By this reaction, cleavage of the ether linkage is prepared because the hemiacetal formed is unstable and decomposes easily to form acetaldehyde and phenol (Fig. 3).

This reaction mechanism is probably the same as that in the cleavage of the alkyl ether linkage in anaerobic PEG degradation by $P$. venetianus, Bacteroides $s p$., and a homoacetogenic bacterium (Schramm and Schink 1991; Frings et al. 1992). In all these cases, acetaldehyde was the first product of the ether cleavage reaction. In contrast to PEG cleavage, the phenoxyethanol-degrading enzyme activity was not influenced by added corrinoids (adeno- sylcobalamin, cyanocobalamin, and hydroxocobalamin). Perhaps the hydroxyl shift reaction required for phenoxyethanol cleavage depends on other corrinoids, or corrinoids of the phenoxyethanol-cleaving enzyme of strain LuPhet 1 are bound tightly to the enzyme and cannot be displaced in the enzyme assay by added cobalamins.

In cell-free extracts of strain LuPhet 1 , a coenzyme $B_{12^{-}}$ dependent diol dehydratase activity was detected. This enzyme was inhibited by light and reactivated by added coenzyme $\mathrm{B}_{12}$, indicating that the corrinoid is probably only loosely associated with the enzyme. The phenoxyethanol-degrading enzyme activity was not inhibited by light treatment of the cell-free extract. This result corroborates the assumption that the corrinoid involved in this reaction is tightly bound to the enzyme.

The diol dehydratase activity converts ethylene glycol to acetaldehyde by exchanging a hydroxyl and a hydrogen residue, and releases water. In anaerobic degradation of PEG by $P$. venetianus and another homoacetogenic bacterium, it was speculated that this enzyme could also cleave the ether linkage of PEG by a similar reaction mechanism. However, tests revealed that the PEG-degrading enzymes of these bacteria are definitely different from diol dehydratase (Schramm and Schink 1991; Frings et al. 1992).

The acetaldehyde formed in phenoxyethanol cleavage is oxidized to acetate by an actaldehyde:acceptor oxidoreductase that forms acetyl coenzyme A (Fig. 3). Phosphate acetyltransferase and acetate kinase were also measured in cell-free extracts of the new isolate. The reducing equivalents were used to reduce carbon dioxide to acetate through the carbon monoxide dehydrogenase pathway.

Our results demonstrate that in anaerobic degradation of phenoxyethanol, an alkylaryl ether linkage is cleaved by the same mechanism that is involved in cleavage of the alkyl ether PEG under anoxic conditions. In contrast, phenoxyacetic acid is not degraded by the new isolate. This result indicates that the free terminal hydroxyl group of phenoxyethanol is required to allow cleavage of the alkylaryl ether linkage by a hydroxyl shift reaction. In contrast, phenoxyacetic acid is degraded to carbon dioxide very slowly by an enrichment culture with sulfate as electron acceptor, but the mechanism of the cleavage of the alkylaryl ether linkage has not yet been determined (unpublished results).
Fig. 3 Proposed pathway for anaerobic phenoxyethanol degradation by strain LuPhet1
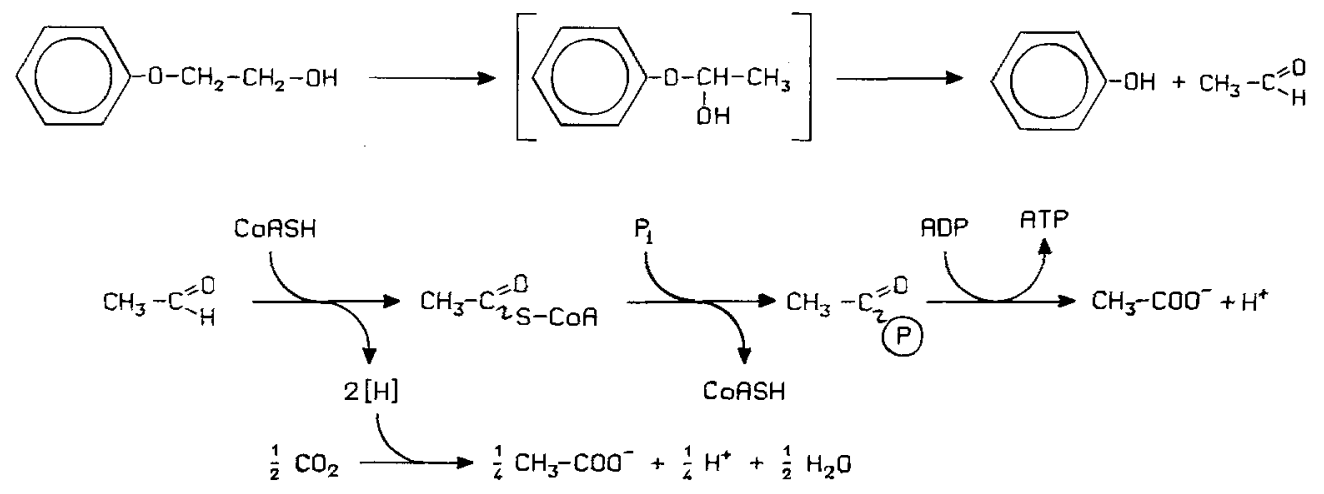


\section{Energetics}

Conversion of phenoxyethanol to phenol and acetaldehyde is an exergonic reaction [calculation after Thauer et al. 1977 ; the $\Delta \mathrm{Gf}^{0}$ value for phenoxyethanol, -100.87 $\mathrm{kJ} / \mathrm{mol}$, was calculated after the increment method (D'Ans and Lax 1983)].

$\mathrm{C}_{6} \mathrm{H}_{5} \mathrm{OCH}_{2} \mathrm{CH}_{2} \mathrm{OH} \rightarrow \mathrm{C}_{6} \mathrm{H}_{5} \mathrm{OH}+\mathrm{CH}_{3} \mathrm{CHO}$

$\Delta \mathrm{G}^{0^{\circ}}=-86.6 \mathrm{~kJ} / \mathrm{mol}$ phenoxyethanol

Fermentation of acetaldehyde to acetate is also an exergonic process:

$4 \mathrm{CH}_{3} \mathrm{CHO}+2 \mathrm{CO}_{2}+2 \mathrm{H}_{2} \mathrm{O} \rightarrow 5 \mathrm{CH}_{3} \mathrm{COO}^{-}+5 \mathrm{H}^{+}$

$\Delta \mathrm{G}^{0^{\prime}}=55.9 \mathrm{~kJ} / \mathrm{mol}$ acetaldehyde

The free energy of phenoxyethanol conversion to phenol and acetaldehyde is probably not conserved by strain LuPhet1; the corresponding PEG cleavage reaction are also not exploited energetically (Schink and Stieb 1983; Schramm and Schink 1991). Fermentation of acetaldehyde to acetate includes a substrate level phosphorylation step and more energy could be conserved in homoacetogenic acetate synthesis. If a growth yield of about $10 \mathrm{~g}$ cell dry mass per mol ATP synthesized is assumed (Stouthammer 1979), the cell yield obtained in this study ( $2.6 \mathrm{~g} / \mathrm{mol}$ acetaldehyde) is comparably low. A similar cell yield was also measured in diethylene glycol fermentation by strain LuPhet $1(5.4 \mathrm{~g} / \mathrm{mol}$ diethylene glycol $=2.7 \mathrm{~g} / \mathrm{mol}$ acetaldehyde) indicating that acetaldehyde fermentation probably involves energy consuming steps such as reversed electron transport or electrogenic product transport processes.

\section{Taxonomy}

The new isolate, strain LuPhet1, was assigned to the genus Acetobacterium on the basis of morphological and physiological properties (Schink and Bomar 1991). The gram-positive, non-sporeforming bacterium was able to reduce carbon dioxide to acetate through the carbon monoxide dehydrogenase pathway; the $\mathrm{G}+\mathrm{C}$ content of the DNA was determined to be $44.3 \pm 0.6 \mathrm{~mol} \%$. Like other species of the genus Acetobacterium, strain LuPhet1 used $\mathrm{H}_{2} / \mathrm{CO}_{2}, 3,4,5$,-trimethoxybenzoate, 3,4,5-trimethoxycinnamate, ethylene glycol, 1,2-propanediol, acetoin, glycerol, lactate, pyruvate, fructose, and betaine as growth substrates. Methanol, ethanol, propanol, butanol, ethanol, ethanolamine, and choline were not fermented. From its substrate utilization pattern, the new isolate most closely resembles Acetobacterium malicum by its capacity to grow also with methoxyethanol and ethoxyethanol (Tanaka and Pfennig 1988). However, A. malicum is not able to ferment phenoxyethanol and PEG. Strain LuPhet1 therefore could be considered as another strain within the species A. malicum. The new isolate was deposited with the Deutsche Sammlung für Mikroorganismen GmbH, Braunschweig, Germany, under DSM 9077.
Acknowledgements This study was supported by the Bundesministerium für Forschung und Technologie (BMFT), Bonn, in its special research program on biotechnology of coal.

\section{References}

Adler E (1977) Lignin chemistry past, present, and future. Wood Sci Technol 11:169-218

Bartholomew JW (1962) Variables influencing results and the precise definition of steps in gram staining as a means of standardizing the results obtained. Stain Technol 37:139-155

Bergmeyer HU (1983) Methods of enzymatic analysis, vol 2-3. Verlag Chemie, Weinheim

Bernhardt FH, Staudinger H, Ullrich V (1970) Eigenschaften einer $p$-Anisat- $O$-Demethylase im zellfreien Extrakt von Pseudomonas species. Z Physiol Chem 351:467-478

Bradford MM (1976) A rapid and sensitive method for the quantitation of microgram quantities of protein utilizing the principle of protein-dye binding. Anal Biochem 72:248-254

Brune A, Schink B (1990) Pyrogallol-to-phloroglucinol conversion and other hydroxyl-transfer reactions catalyzed by cell extracts of Pelobacter acidigallici. J Bacteriol 172: 1070-1076

D'Ans J, Lax E (1983) Taschenbuch für Chemiker und Physiker, 4th edn. (Organische Verbindungen, vol 2) Springer, Berlin Heidelberg New York, pp 1003-1006

Diekert G, Thauer RK (1978) Carbon monoxide oxidation by Clostridium thermoaceticum and Clostridium formicoaceticum. J Bacteriol 136:597-606

Frings J, Schramm E, Schink B (1992) Enzymes involved in anaerobic polyethylene glycol degradation by Pelobacter venetianus and Bacteroides strain PG 1. Appl Environ Microbiol $58: 2164-2167$

Ghosal D, You I-S, Chatterjee DK, Chakrabarty AM (1985) Microbiol degradation of halogenated compounds. Science 228 : 135-142

Heredy LA, Wender I (1980) Model structure for a bituminous coal. Am Chem Soc Div Fuel Chem 25:38-45

Marmur J (1961) A procedure for the isolation of deoxyribonucleic acid from micro-organisms. J Mol Biol 3:208-218

Mesbah M, Premachandran U, Whitman W (1989) Precise measurement of the $\mathrm{G}+\mathrm{C}$ content of deoxyribonucleic acid by high performance liquid chromatography. Int J Syst Bacteriol 39: 159-167

Odom JM, Peck HD (1981) Localization of dehydrogenases, reductases, and electron transfer components in the sulfate-reducing bacterium Desulfovibrio gigas. J Bacteriol 147: 161-169

Pfennig N (1978) Rhodocyclus purpureus gen. nov. and sp. nov., a ring shaped, vitamin $\mathrm{B}_{12}$-requiring member of the family Rhodospirillaceae. Int J Syst Bacteriol 28:283-288

Platen H, Schink B (1987) Methanogenic degradation of acetone by an enrichment culture. Arch Microbiol 149:136-141

Schink B, Bomar M (1991) The genera Acetobacterium, Acetogenium, Acetoanaerobium, and Acetitomaculum. In: Balows A, Trüper HG, Dworkin M, Harder W, Schleifer KH (eds) The procaryotes, 2nd edn., vol 1. Springer, Berlin Heidelberg New York,pp 1925-1936

Schink B, Stieb M (1983) Fermentative degradation of polyethylene glycol by a stricly anaerobic, gram-negative, non-sporeforming bacterium, Pelobacter venetianus sp. nov. Appl Environ Microbiol 45: 1905-1913

Schramm E, Schink B (1991) Ether-cleaving enzyme and diol dehydratase involved in anaerobic polyethylene glycol degradation by a new Acetobacterium sp. Biodegradation 2:71-79

Stirling DI, Dalton H (1980) Oxidation of dimethyl ether, methylformate and bromomethane by Methylococcus capsulatus (Bath). J Gen Microbiol 116:277-283

Stouthamer AH (1979) The search for correlation between theoretical and experimental growth yields. Int Rev Biochem $21: 1-47$

Tamaoka J, Komagata K (1984) Determination of DNA base composition by reversed-phase high-performance liquid chromatography. FEMS Microbiol Lett 25:125-128 
Tanaka K, Pfennig N (1988) Fermentation of 2-methoxyethanol by Acetobacterium malicum sp. nov. and Pelobacter venetianus. Arch Microbiol 149:181-187

Thauer RK, Jungermann K, Decker K (1977) Energy conservation in chemotrophic anaerobic bacteria. Bacteriol Rev 41:100-180

Toraya T, Fukui S (1982) Diol dehydrase. In: Dolphin D (ed) $B_{12}$, vol 2. Wiley, New York, pp 233-262

Tschech A, Pfennig N (1984) Growth yield increase linked to caffeate reduction in Acetobacterium woodii. Arch Microbiol $137: 163-167$
Widdel F, Pfennig N (1981) Studies on dissimilatory sulfate-reducing bacteria that decompose fatty acids. I. Isolation of new sulfate-reducing bacteria enriched with acetate from saline environments. Description of Desulfobacter postgatei gen. nov. sp. nov. Arch Microbiol 129:395-400

Widdel F, Kohring GW, Mayer F (1983) Studies on dissimilatory sulfate-reducing bacteria that decompose fatty acids. III. Characterization of the filamentous gliding Desulfonema limicola gen. nov. sp. nov, and Desulfonema magnum sp. nov. Arch Microbiol $134: 286-294$ 